\title{
Development of an EGFRvIll specific recombinant antibody
}

\author{
Puja Gupta', Shuang-Yin Han ${ }^{1,2}$, Marina Holgado-Madruga', Siddhartha S Mitra', Gordon Li', Ryan T Nitta', \\ Albert J Wong ${ }^{1 *}$
}

\begin{abstract}
Background: EGF receptor variant III (EGFRvIII) is the most common variant of the EGF receptor observed in human tumors. It results from the in frame deletion of exons 2-7 and the generation of a novel glycine residue at the junction of exons 1 and 8. This novel juxtaposition of amino acids within the extra-cellular domain of the EGF receptor creates a tumor specific and immunogenic epitope. EGFRvIll expression has been seen in many tumor types including glioblastoma multiforme (GBM), breast adenocarcinoma, non-small cell lung carcinoma, ovarian adenocarcinoma and prostate cancer, but has been rarely observed in normal tissue. Because this variant is tumor specific and highly immunogenic, it can be used for both a diagnostic marker as well as a target for immunotherapy. Unfortunately many of the monoclonal and polyclonal antibodies directed against EGFRvIII have cross reactivity to wild type EGFR or other non-specific proteins. Furthermore, a monoclonal antibody to EGFRvIll is not readily available to the scientific community.
\end{abstract}

Results: In this study, we have developed a recombinant antibody that is specific for EGFRvIll, has little cross reactivity for the wild type receptor, and which can be easily produced. We initially designed a recombinant antibody with two anti-EGFRvIll single chain Fv's linked together and a human IgG1 Fc component. To enhance the specificity of this antibody for EGFRvIII, we mutated tyrosine $\mathrm{H} 59$ of the $\mathrm{CDRH} 2$ domain and tyrosine $\mathrm{H} 105$ of the CDRH3 domain to phenylalanine for both the anti-EGFRvIll sequence inserts. This mutated recombinant antibody, called RAb ${ }^{\text {DMvill }}$, specifically detects EGFRvIll expression in EGFRvIll expressing cell lines as well as in EGFRvIll expressing GBM primary tissue by western blot, immunohistochemistry (IHC) and immunofluorescence (IF) and FACS analysis. It does not recognize wild type EGFR in any of these assays. The affinity of this antibody for EGFRvIll peptide is $1.7 \times 10^{7} \mathrm{M}^{-1}$ as determined by enzyme-linked immunosorbent assay (ELISA).

Conclusion: This recombinant antibody thus holds great potential to be used as a research reagent and diagnostic tool in research laboratories and clinics because of its high quality, easy viability and unique versatility. This antibody is also a strong candidate to be investigated for further in vivo therapeutic studies.

\section{Background}

According to Global Health Council despite advances in the understanding of cancer biology, malignant neoplasms remain the second leading cause of mortality in United States. Novel therapies are needed and over the past two decades new immunotherapy strategies have emerged as a promising approach. The success of these immunotherapeutic strategies is highly dependent on

\footnotetext{
* Correspondence: ajwong@stanford.edu

'Brain Tumor Research Laboratories, Department of Neurosurgery, and Program in Cancer Biology, Stanford University Medical Center, Stanford, CA94305, USA

Full list of author information is available at the end of the article
}

finding an ideal antigen to target. One such target is the EGF receptor which is over or aberrantly expressed in a variety of human cancers [1-12]. However, the fact that the EGF receptor is present on normal tissue could lead to possible deleterious side effects or immune tolerance when treating patients with reagents solely targeting the EGF receptor. A tumor specific antigen would be more ideal. Epidermal growth factor receptor variant III (EGFRvIII) is the most common variant of the EGF receptor and is expressed in a number of solid tumors including glioblastoma multiforme (GBM), breast adenocarcinoma, medulloblastoma and ovarian adenocarcinoma, but has only rarely been observed in normal
C Biomed Central

() 2010 Gupta et al; licensee BioMed Central Ltd. This is an Open Access article distributed under the terms of the Creative Commons Attribution License (http://creativecommons.org/licenses/by/2.0), which permits unrestricted use, distribution, and reproduction in any medium, provided the original work is properly cited. 
tissue [13-15]. This variant receptor results from an inframe deletion of exons 2-7 of the wild type EGF receptor. This causes a deletion of a large portion of the extracellular domain and the generation of a novel glycine at the fusion junction between exon 1 and exon 8 [16-18]. EGFRvIII is ligand independent yet constitutively active and when expressed in cells it leads to unregulated growth, survival, invasion, and angiogenesis [19]. EGFRvIII is an ideal target for immunotherapy because the juxtaposition of exon 1 and 8 sequences plus the novel glycine creates a highly immunogenic tumor specific antigen, and the receptor itself leads to a cancer phenotype due to its constitutive activity [1,20-22].

There are a number of immune approaches that specifically target EGFRvIII. For example, a peptide vaccine targeting this mutant receptor is currently being tested in clinical trials for GBM patients [23,24]. Another approach is the development of antibodies that recognize EGFRvIII which can be used for diagnostic/laboratory purposes or for therapeutic purposes either alone or attached to a cytotoxic or radiolabeled adjunct $[25,26]$. Many of the monoclonal antibodies that target EGFRvIII, however, have cross reactivity with the wild type EGF receptor or other non-specific proteins [27] or comparatively have low affinity. While polyclonal antibodies are apparently highly sensitive and of high affinity, it is difficult to produce them in mass quantities. An additional complicating factor is that the rights to the antibody for EGFRvIII are patented and have not been made widely available for either scientific or medical use.

To generate a highly specific and cost effective antibody that could be used for scientific and clinical purposes, we developed a recombinant antibody. Recombinant antibody technology has gained popularity in recent years because of its many advantages when compared with the production of monoclonal or polyclonal antibodies. First, no animals are needed and the manufacturing time is relatively short compared with conventional methods. Moreover, the quality and quantity of the final product is superior when compared to conventional antibody production. Recombinant antibodies are formed by combining single-chain $\mathrm{Fv}$ antibodies, consisting of $\mathrm{V}_{\mathrm{H}}$ and $\mathrm{V}_{\mathrm{L}}$ chains, by a flexible linker [28]. In this report, we describe how we created a recombinant antibody that specifically recognizes EGFRvIII and demonstrate its specificity by western blot analysis, immunohistochemistry (IHC), immunofluorescence (IF), enzyme-linked immunosorbent assay (ELISA) and flow cytometry analysis (FACS). This easily produced and highly specific recombinant antibody holds great potential to be used as a diagnostic and a therapeutic tool.

\section{Results}

\section{Western Analysis}

We constructed the first recombinant EGFRvIII antibody, $\mathrm{RAb}^{\text {vIII }}$, using the sequence of MR1-1, an scFv developed against EGFRvIII (Figure 1) [29]. To determine the specificity of RAb ${ }^{\text {vIII }}$ antibody for EGFRvIII, we used it for western blot analysis. Consistent with previously published data, the RAb ${ }^{\mathrm{vIII}}$ antibody recognizes the $145 \mathrm{kDa}$ EGFRvIII protein band in U87-vIII cells stably expressing EGFRvIII (U87-vIII) compared to the U87-MG untransfected cells (Figure 2A) [30]. The RAb ${ }^{\mathrm{vIII}}$ antibody also faintly recognized the endogenous $170 \mathrm{kDa}$ wild type EGF receptor and it strongly recognize a $45 \mathrm{kDa}$ protein band in both U87-vIII and U87-MG control cells. We speculated that the $45 \mathrm{kDa}$ protein was cross-reaction with another EGF receptor variant that we have recently identified, called mLEEK. MiniLEEK (mLEEK) is the result of the fusion of exon 1 to exon 23 and is predicted to be $45 \mathrm{kDa}$ in size (Piccione et al., submitted). This also creates a glycine at the junction and the fusion junction (LEEKKGVTVWEL) bears some resemblance to the EGFRvIII sequence.

The crystal structure of MR1-1 in complex with the EGFRvIII peptide has been done by Landry et al. [31] This shows the valine at P9 position of the EGFRvIII peptide forms a hydrogen bond with tyrosine at H59 and H105 on MR1-1. The mLEEK peptide has a valine at the identical position. Since RAb ${ }^{\mathrm{vIII}}$ potentially cross reacted with $\mathrm{mLEEK}$, to eliminate the non-specific 45 $\mathrm{kDa}$ band we mutated the tyrosines at $\mathrm{H} 59$ and $\mathrm{H} 105$ to phenylalanine.

To determine if the mutated $\mathrm{RAb}^{\mathrm{DMvIII}}$ has improved specificity towards EGFRvIII, we conducted another western analysis. We found that RAb ${ }^{\text {DMvIII }}$ now specifically recognizes only the EGFRvIII $145 \mathrm{kDa}$ protein band and not the EGFR variant $45 \mathrm{kDa}$ band (Figure $2 \mathrm{~A}$ ). We also more rigorously tested cross-reaction with wt EGF receptor by performing Western blots using lysates from A431 cells, which express $1 \times 10^{6}$ receptors per cell. When we studied the specificity of RAb ${ }^{\text {DMvIII }}$ towards the overexpressed wild type EGFR present in A431 cells we discovered that the RAb ${ }^{\text {DMvIII }}$ antibody did cross-react with the $170 \mathrm{kDa}$ wild type protein (Figure 2B).

Consequently, to further study the specificity of the $\mathrm{RAb}^{\mathrm{DMvIII}}$ under these conditions we expanded our analysis to include $\mathrm{HC} 2$ cells which expresses EGFRvIII at a level comparable to that of EGFR expressed by A431 (Figure 2B). Western analysis using anti-EGFR antibody E3138 from Sigma shows that there are similar amounts of wild type EGFR and EGFRvIII protein expressed in A431 and HC2 cells (Figure 2B).

Based on the study done by Johns et al. which showed that monoclonal antibody 806 recognizes overexpressed 


\section{di-EGFRvIll-scFv Antibody}

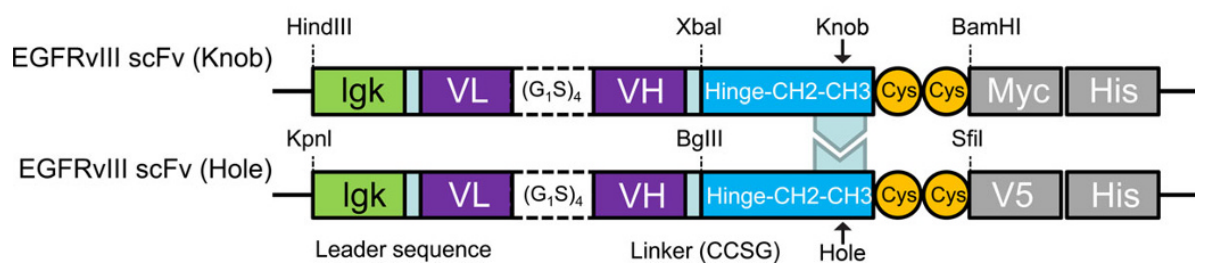

Figure 1 Schematic of the RAb $\mathbf{D}^{\text {DMvllI }}$ antibody. The genes for the anti-EGFRvIll scFvs were cloned into the pBudCE4.1 dicistronic vector. The Ig k-chain signal sequence at the $5^{\prime}$ end of each sequence allowed the secretion of the molecule in the culture media. "Knobs-into-holes" configuration and the two cysteine residues at the $3^{\prime}$ end of each $\mathrm{CH} 3$ domain stabilize the construct. Sequence corresponding to a $\mathrm{V} 5$ epitope was cloned at the $3^{\prime}$ end of one anti-EGFR scFvs and the other anti-EGFR scFv has Myc as well as a 6xHis tag at 3'end.

EGFR in A431 cells only under reducing conditions, we further analyzed both $\mathrm{HC} 2$ and A431 cell lysates under non-reducing western conditions [32]. Western analysis under these conditions shows that recombinant $\mathrm{RAb}^{\mathrm{DMvIII}}$ recognizes only the EGFRvIII $145 \mathrm{kDa}$ band and not the wild type EGFR $170 \mathrm{kDa}$ band (Figure $2 \mathrm{C}$ ) suggesting that under reducing conditions the EGFR epitope is somewhat more exposed and accessible to RAb ${ }^{\text {DMvIII }}$ [32]. On the other hand, the non mutated RAb ${ }^{\text {vIII }}$ consistently recognizes the $170 \mathrm{kDa}$ wild type EGFR band even under nonreducing western conditions clearly illustrating that $\mathrm{RAb}^{\mathrm{DMvIII}}$ is a more specific EGFRvIII antibody than $\mathrm{RAb}^{\mathrm{vIII}}$.

\section{Antibody Affinity}

To determine the affinity constant of the antibody, we used the method described by Friguet et al. (1984) [33]. It is necessary that the concentration of the antibody used in the ELISA should be equal to or less than the value of dissociation constant of the antibody. Thus a preliminary ELISA was performed to deduce the dissociation constant of the antibody. From the preliminary ELISA, the dissociation constant of RAb ${ }^{\mathrm{vIII}}$ and $\mathrm{RAb}^{\mathrm{DM}-}$ vIII is calculated to be approximately $1.7 \mu \mathrm{M}$ and 886 $\mathrm{nM}$, respectively, against EGFRvIII peptide (Figure 3A). This result suggests that $\mathrm{RAb}^{\mathrm{DMvIII}}$ did not lose its affinity after mutation as $\mathrm{RAb}^{\mathrm{DMvIII}}$ has a lower dissociation constant than $\mathrm{RAb}^{\mathrm{vIII}}$.

The indirect ELISA was performed with $\mathrm{RAb}^{\mathrm{DMvIII}}$ using a concentration of $117 \mathrm{nM}$, which is lower than its dissociation constant value of $886 \mathrm{nM}$. The OD values from this ELISA were placed in a Scatchard plot equation where the fraction of bound antibody sites $\alpha$ (determined from the OD values) is plotted on the $\mathrm{X}$ axis and the ratio of the fraction of bound antibody sites $\alpha$ to free antigen sites $c,(\alpha / c)$ is plotted on the Y axis. The slope gives the value of $-K$, the affinity constant of the antibody, which is $1.7 \times 10^{7} \mathrm{M}^{-1}$ (Figure 3B).

\section{Immunoprecipitation}

Immunoprecipitation of $\mathrm{HC} 2$ and $\mathrm{A} 431$ cell lysates was performed using RAb ${ }^{\text {DMvIII }}$ and G100 an anti-EGFRvIII monoclonal antibody (no longer commercially available). As a negative recombinant antibody control for EGFR wt and EGFRvIII, we also used RAb ${ }^{\mathrm{CD} 133}$, which utilizes the same expression vector as RAb ${ }^{\text {DMvIII }}$ but is directed against CD133 and recognizes neither EGFR wt nor EGFRvIII. HC2 cell lysates immunoprecipitated with $\mathrm{RAb}^{\mathrm{DMvIII}}$ and G100 antibody and then further immunoblotted with E3138 antibody showed the expected 145 $\mathrm{kDa}$ band corresponding to EGFRvIII in the pellet whereas $\mathrm{RAb}^{\mathrm{CD} 133}$ did not show the $145 \mathrm{kDa}$ band in the pellet as it does not bind to EGFRvIII (Figure 4A) On the contrary, when A431 cell lysates were immunoprecipitated with either $\mathrm{RAb}^{\mathrm{DMvIII}}, \mathrm{G} 100$ or $\mathrm{RAb}^{\mathrm{CD} 133}$ and then immunoblotted with the E3138 antibody, the170 $\mathrm{kDa}$ bands corresponding to wt EGFR was found in the supernatant (Figure 4B). This suggested that even when abundant amounts of wt EGFR protein is present $\mathrm{RAb}^{\text {DMvIII }}$ did not bind to any wild type EGFR.

\section{Immunofluorescence}

Since the specificity of RAb ${ }^{\text {DMvIII }}$ is greatly enhanced under native conditions, we decided to test the recombinant antibody specificity under in vivo conditions. To this end, indirect immunofluorescence was performed on $\mathrm{HC} 2$ and $\mathrm{A} 431$ cells with $\mathrm{RAb}^{\text {DMvIII }}$ at a concentration of $0.25 \mu \mathrm{g} / \mu \mathrm{l}$. Images were taken using a Leica SP2 AOBS confocal microscope. Consistent with previous findings, the $\mathrm{RAb}^{\mathrm{DMvIII}}$ shows that the EGFRvIII protein is both membrane bound and has an intracellular localization (Figure 5A) [1,6,34]. To verify the specificity of the $\mathrm{RAb}^{\mathrm{DMvIII}}$ antibody we conducted a peptide competition using the EGFRvIII epitope (LEEKKGNYVVTDHC). The presence of the EGFRvIII epitope completely blocked $\mathrm{RAb}^{\mathrm{DMvIII}}$ from interacting with the EGFRvIII found in the $\mathrm{HC} 2$ cells (Figure 5C), as compared to the scramble 


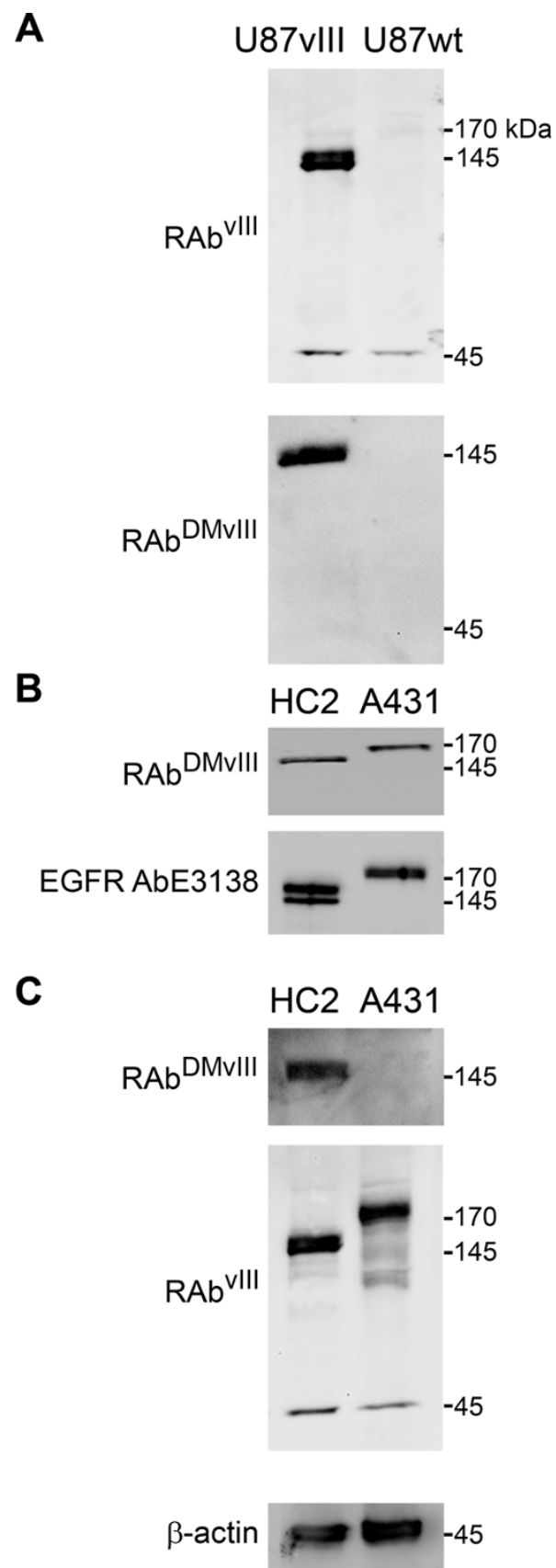

Figure 2 Western Blot analysis of RAb ${ }^{\text {DMvllI }}$ antibody. A) 30 ug of U87vIII and U87 wild type cell lysate loaded under reducing conditions on 4-20\% SDS-PAGE. A) RAb ${ }^{\text {vll }}$ recognizes $145 \mathrm{kDa}$ band which corresponds to the EGFRvIll and $45 \mathrm{kDa}$ unspecific protein band. A) RAb DMvlll recognizes only $145 \mathrm{kDa}$ protein band. B) RAb ${ }^{\text {DMvll }}$ recognizes $170 \mathrm{KDa}$ protein band in 30 ug of A431 cell lysate (cells overexpressing EGFR) and $145 \mathrm{kDa}$ band in $30 \mathrm{ug}$ of HC2 cell lysate under reducing conditions. B) EGFR antibody recognizes equal amount of protein in both $\mathrm{HC2}$ and $\mathrm{A} 431$ cell lysate under reducing conditions. C) RAb ${ }^{\text {DMvlll }}$ under non reducing conditions detect only $145 \mathrm{kDa}$ protein band whereas RAb ${ }^{\text {vll }}$ still recognizes $145 \mathrm{kDa}$ and $170 \mathrm{kDa}$ protein bands in non reducing conditions. C) Actin antibody under reducing condition shows equal amount of protein loaded in the wells. epitope control which showed no decrease in detection of EGFRvIII (Figure 5B). Additionally, the A431 cells that over express wild type EGFR did not demonstrate any signal with $\mathrm{RAb}^{\mathrm{DMvIII}}$ (Figure 5D), whereas the antiEGFR antibody recognizes a strong EGFR wild type signal demonstrating that the A431cells retain high expression of the wild type protein (Figure 5E). Together these findings indicate again that this recombinant antibody is highly specific towards EGFRvIII.

\section{Immunohistochemistry}

Immunohistochemistry (IHC) is another sensitive biochemical test to monitor for the expression of EGFRvIII. To determine if the RAb ${ }^{\text {DMvIII }}$ antibody could be used for IHC, we used mouse tumor xenografts from HC2 and A431 cells (Figure 6A-C) and GBM cases (Figure 6D-G). The tumor xenografts contain both $\mathrm{HC} 2$ tissue (top) and A431 tissue (bottom). RAb ${ }^{\text {DMvIII }}$ shows strong positivity to the $\mathrm{HC} 2$ section which is comparable in intensity to slides stained with the positive control antiEGFRvIII polyclonal antibody (Figure 6A \&6B). In addition, the RAb ${ }^{\text {DMvIII }}$ antibody did not stain the A431 tissue sections (Figure 6A). The recombinant antibody $\mathrm{RAb}^{\mathrm{CD} 133}$ was used as a negative antibody control (Figure $6 \mathrm{C})$. We extended our findings to two GBM cases, one positive for EGFRvIII (08023) and one negative (0434497). Consistent with the mouse tumor xenografts, the $\mathrm{RAb}^{\mathrm{DMvIII}}$ antibody only stained the GBM positive for EGFRvIII and had no cross reactivity to the negative GBM case (Figure 6D \&6F). As a control, we also stained these sections with affinity purified polyclonal anti-EGFRvIII and observed similar results (Figure 6E and $6 G)$.

\section{Flow cytometry}

Because RAb ${ }^{\text {DMvIII }}$ efficiently detects surface EGFRvIII, we asked if it might be an effective reagent for flow cytometry experiments. Under native conditions we observed that $\mathrm{RAb}^{\mathrm{DMvIII}}$ binds to surface expressed EGFRvIII very efficiently. Figure 7A shows an overlay of plots from $\mathrm{HC} 2$ cells stained with increasing concentration of $\operatorname{RAb}^{\text {DMvIII }}\left(0.1 \mu \mathrm{g}, 1 \mu \mathrm{g}\right.$ and $2 \mu \mathrm{g}$ per $10^{6}$ cells $)$. The dot blot and histogram in blue represents humanIgG1 isotype control and as low as 0.1 ug of RAb ${ }^{\text {DMvIII }}$ shows a significant shift in fluorescence intensity. Higher concentration of $\mathrm{RAb}^{\mathrm{DMvIII}}(1 \mu \mathrm{g}$ and $2 \mu \mathrm{g})$ show the presence of multiple peaks consistent with the immunofluorescence assay (Figure 5) which shows different levels of EGFRvIII expression. To look at the sensitivity of $\mathrm{RAb}^{\mathrm{DMvIII}}$ in identifying and isolating EGFRvIII expressing cells, we mixed NIH3T3 and HC2 cells at a $1: 1$ stoichiometry prior to staining with $\mathrm{RAb}^{\mathrm{DMvIII}}$. $\mathrm{RAb}^{\mathrm{DMvIII}}$ was able to clearly identify and separate the HC2 cells from NIH3T3 cells. 


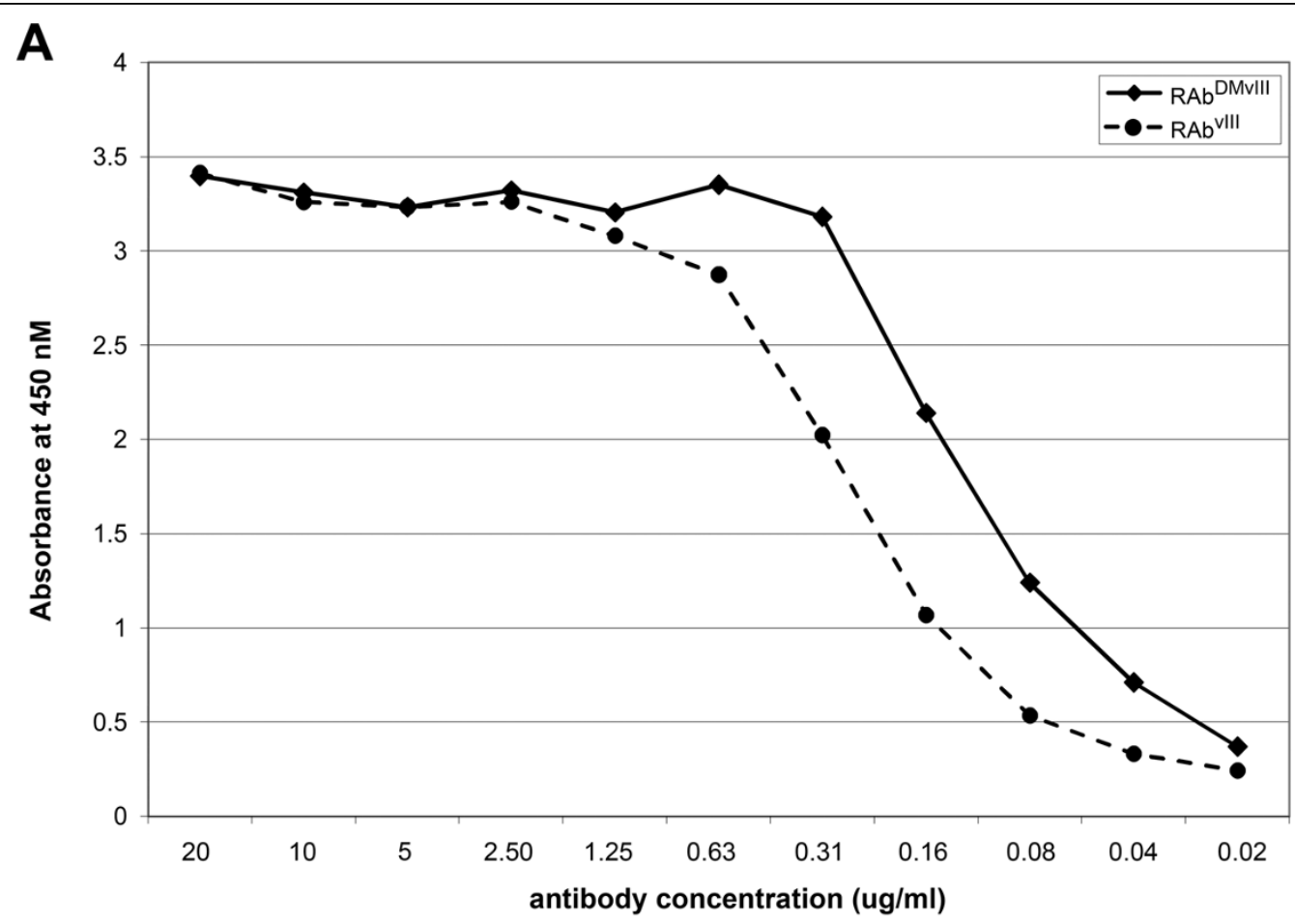

B

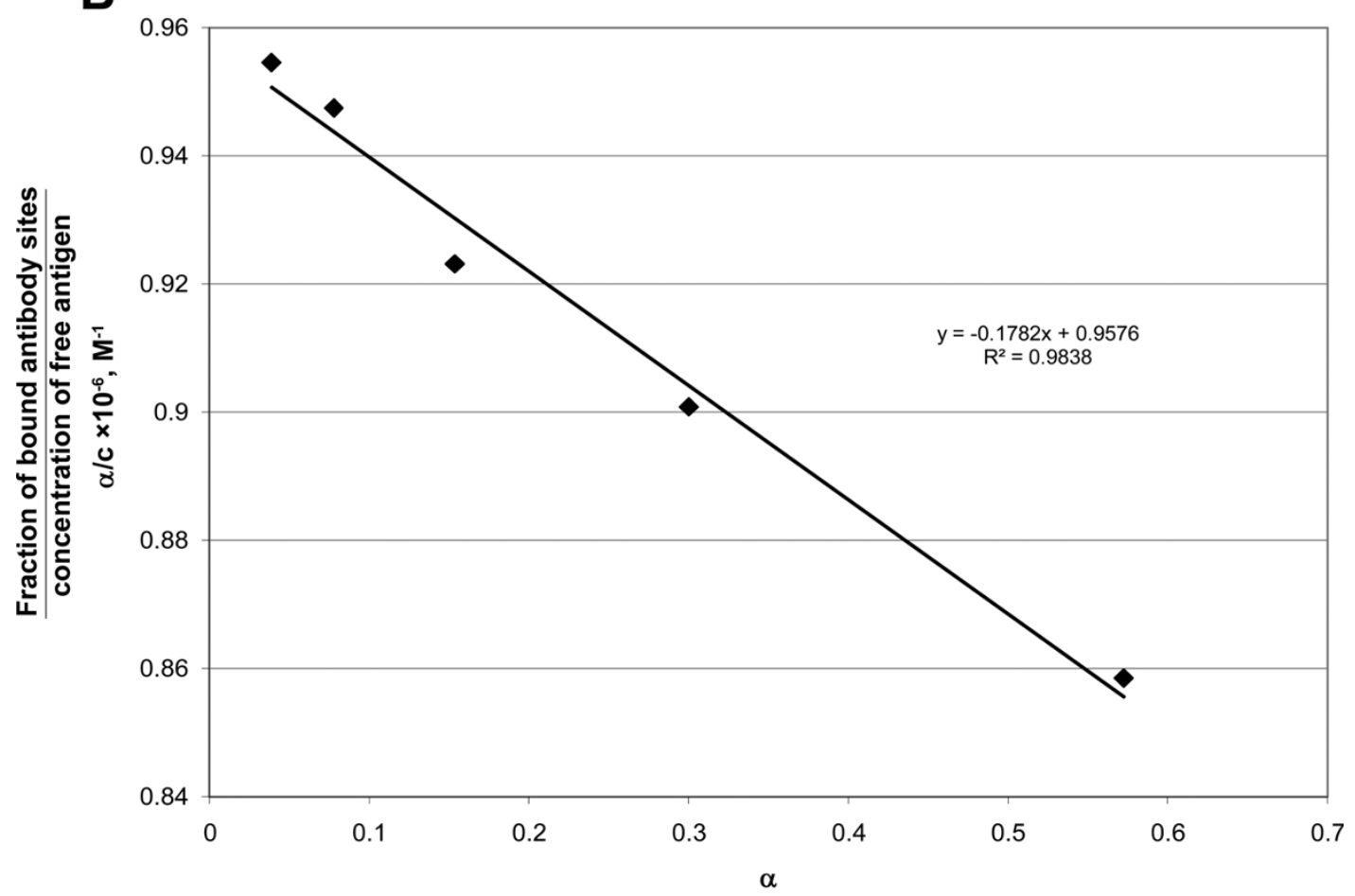

Fraction of bound antibody sites

Figure 3 Affinity determination of RA $\mathbf{b}^{\text {DMvllI }}$ by Saturation ELISA. Calibration curve of the binding of RAb $b^{\text {DMvll }}$ and RAb ${ }^{\text {vIll }}$ recombinant antibodies to coated EGFRvIll in the ELISA. A) The concentration range for RAb ${ }^{\text {DMvlll }}$ and RAb ${ }^{\text {vll }}$ was 20 to $0.02 \mathrm{ug} / \mathrm{ml}(\mathrm{x}$ axis) and the absorbance was read at $450 \mathrm{~nm}$ (Y axis). The assay was analyzed twice. B) Saturation ELISA shows the Scatchard plot of the binding of RAb DMvlll to EGFRvIll. The resulting data is plotted as ratio of $\alpha / c$ (y axis) as function of alpha ( $x$ axis) where $\alpha$ is the fraction of bound antibody sites and $c$ is the concentration of free antigen. The slope is $-\mathrm{K}$ which is the affinity constant of antibody and that is $1.7 \times 10^{7}$ liters $/ \mathrm{mole}^{-1}\left(\mathrm{M}^{-1}\right)$. 


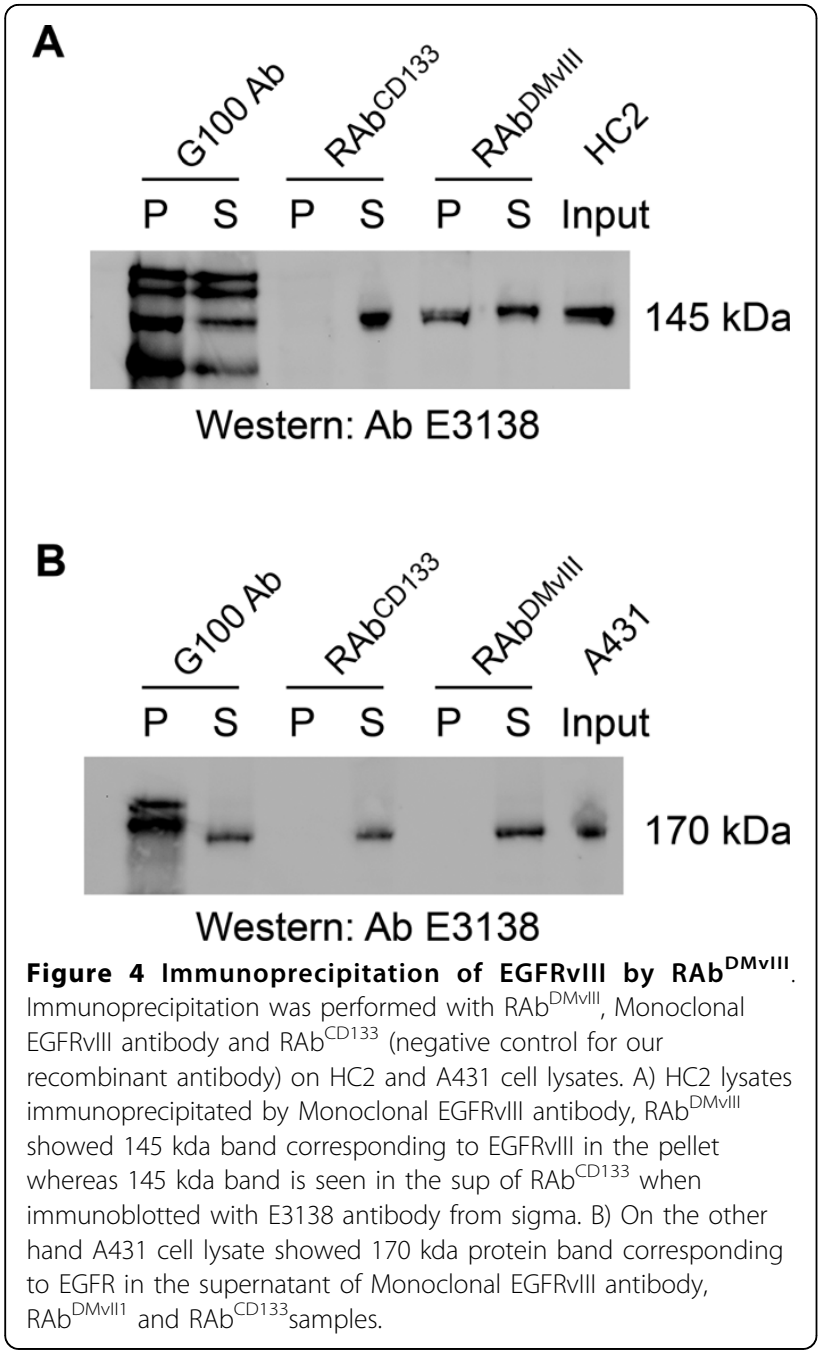

One of the earlier concerns in developing the recombinant EGFRvIII antibodies was the potential cross-reactivity towards wt EGFR under conditions where the receptor is over-expressed such as that in A431 cells. Flow cytometry allows quantitation of any potential cross-reaction under native conditions. Figure $7 \mathrm{C}$ is the overlap of plots of A431 (black) and HC2 (blue) cells with $\mathrm{RAb}^{\text {DMvIII }}$. There is very little reactivity of $\mathrm{RAb}^{\mathrm{DM}-}$ vIII with A431 as compared to $\mathrm{HC} 2$ cells demonstrating that this reagent does not cross-react with wt EGFR. We further tested $\mathrm{RAb}^{\mathrm{DMvIII}}$ for surface staining of freshly primary tumor cells and observed about $14 \%$ of cells to be EGFRvIII positive over the isotype control.

\section{Discussion}

In this work, we have constructed a novel recombinant antibody, RAb ${ }^{\text {DMvIII }}$, which specifically recognizes EGFRvIII. Based upon a previously described $\mathrm{scFv}$ against EGFRvIII, we have performed further mutagenesis to eliminate cross reaction with a $50 \mathrm{kDa}$ band. We have demonstrated the specificity of this antibody for EGFRvIII and not wt EGFR or any other protein by several methods. Unlike other monoclonal anti-EGFRvIII antibodies, this antibody is broadly useful because it recognizes the EGFRvIII epitope in several assays including ELISA, IF, IHC, western blot analysis, and flow cytometry.

A distinct advantage is that recombinantly produced antibodies require no animal for production but otherwise have the properties of conventional antibodies but with additional, improved properties. Indeed, the $\mathrm{RAb}^{\mathrm{DMvIII}}$ has been engineered to have an IgG Fc region, which confers long serum half life, and has selected to support secondary immune functions, such as antibody dependent cellular cytotoxicity (ADCC) and complement mediated cytotoxicity (CMC) [35,36]. Studies have demonstrated that Fc-containing BsAb and other fusion proteins do retain the full effector mechanisms of the Fc component [36,37].

Effective tumor targeting requires that the antibody should have an affinity for its tumor antigen but extremely high affinity may in fact be detrimental [38]. Previous studies have shown that very high affinity interactions of $10^{9}$ $\mathrm{M}^{-1}$ between antibodies and tumor antigens may actually impair efficient tumor penetration of the monoclonal antibodies and thus diminish effective in vivo targeting [39]. Fujimori et al. [40] and Van Osdol et al. [41] have also demonstrated that higher affinity monoclonal antibodies do not homogenously distribute and show less killing of the target cancer cells. According to Robinson et al., a high antibody affinity restricts the localization and tumor penetration of $\mathrm{Fv}$ antibody molecules [42]. In another study, Langmuir et al. [26] have shown that a lower affinity mAb of $5.2 \times 10^{7} \mathrm{M}^{-1}$ was nearly as toxic as a mAb with an affinity of $1.9 \times 10^{9} \mathrm{M}^{-1}$. Our antibody has an affinity of $1.7 \times 10^{7} \mathrm{M}^{-1}$ as shown by saturation ELISA so it could be a reasonable candidate for therapeutic studies.

In separate studies, we have already begun to explore the effectiveness of the $\mathrm{RAb}^{\mathrm{DMvIII}}$ in targeting tumor spheres derived from glioblastoma tumors. These experiments have already shown that this reagent specifically lyse the cells expressing EGFRvIII and spare normal neural stem cells (Mitra et al., submitted). We performed cytotoxicity assays using a coupled luminescence method on various EGFRvIII transfected cell lines with human NK cells as effectors and found that this reagent significantly induces cell killing of EGFRvIII transfected cells. RAb ${ }^{\text {DMvIII }}$ also remarkably reduces the sphere initiating frequency on GBM cells but not in normal cells as it has been shown that EGFRvIII is required for the maintenance of glioma growth in vivo [43]. To further investigate this reagent in mouse models, two GBM sphere lines were incubated with either $\mathrm{RAb}^{\mathrm{DMvIII}}, \mathrm{RAb}^{\mathrm{CD} 133}$ or a non-specific human control 


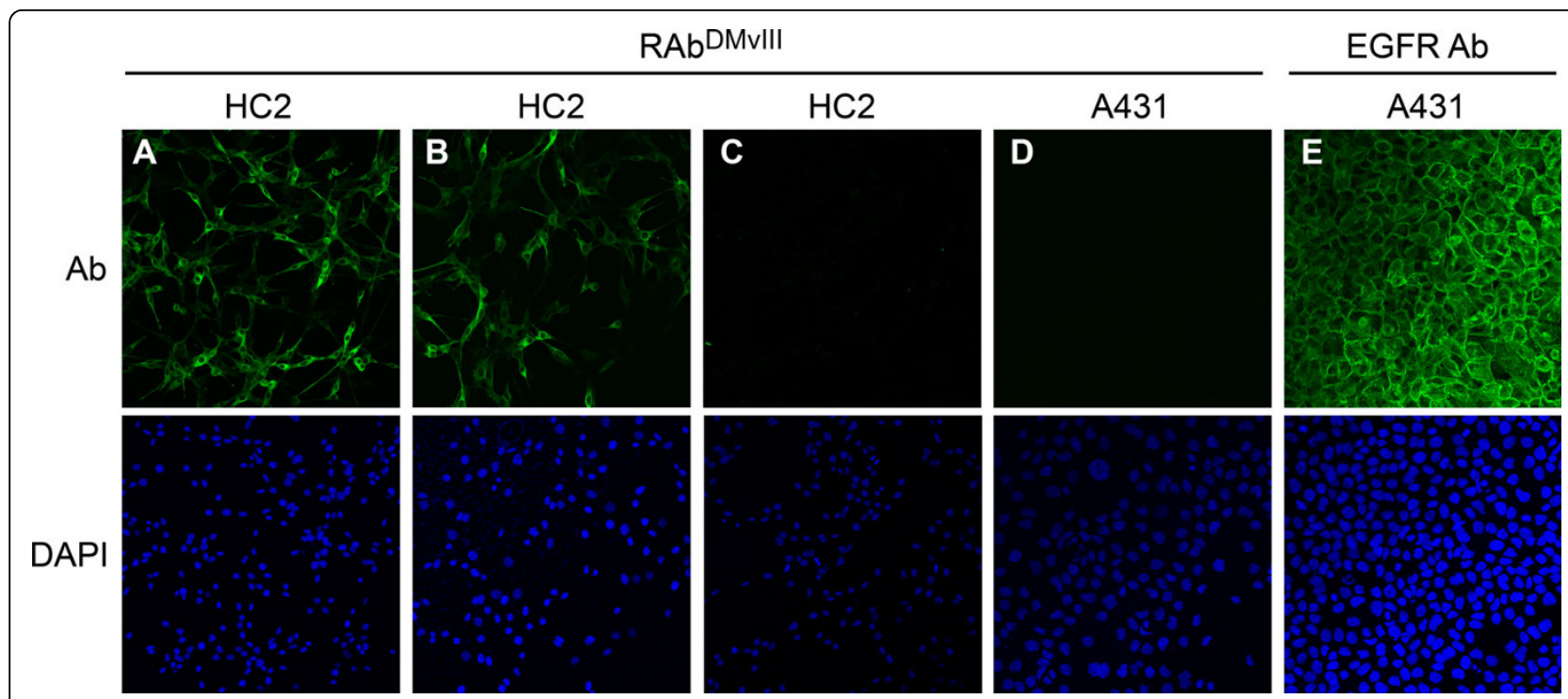

Figure $\mathbf{5}$ Detection of specificity of RAb ${ }^{\text {DMvllI }}$ by Immunofluorescence. A) Immunofluorescence study shows that RAb protein in HC2 cells, B) Scrambled peptide competition shows detection of the EGFRvill signal in HC2 cells by RAb ${ }^{\text {DMvlll }}$, C) Specific peptide (EGFRvIII) competition dampens the signal in HC2 cells, D) No signal is detected in A431 cells by RAb ${ }^{\text {DMvlll }}$ E) EGFR signal is detected in A431 cells by anti-EGFR antibody (sc-130, Santa Cruz).

antibody and orthotopically injected into the cortex of NOD-SCID mice. Tumor formation was analyzed after 26 weeks which revealed a higher incidence of human tumor cells engraftment with $\mathrm{RAb}^{\mathrm{CD} 133}$ and $\mathrm{Hu}-\mathrm{IgG1}$ as compared to RAb ${ }^{\text {DMvIII }}$ (Mitra et al., submitted). In order to provide this reagent to other researchers and for future studies, we are planning to scale up antibody production using hollow fiber bioreactor system. Hence this antibody could be of great significance in the field of brain tumor research.

\section{Conclusion}

Despite significant advances in the field of neuro-oncology and immunology, there is no widely available

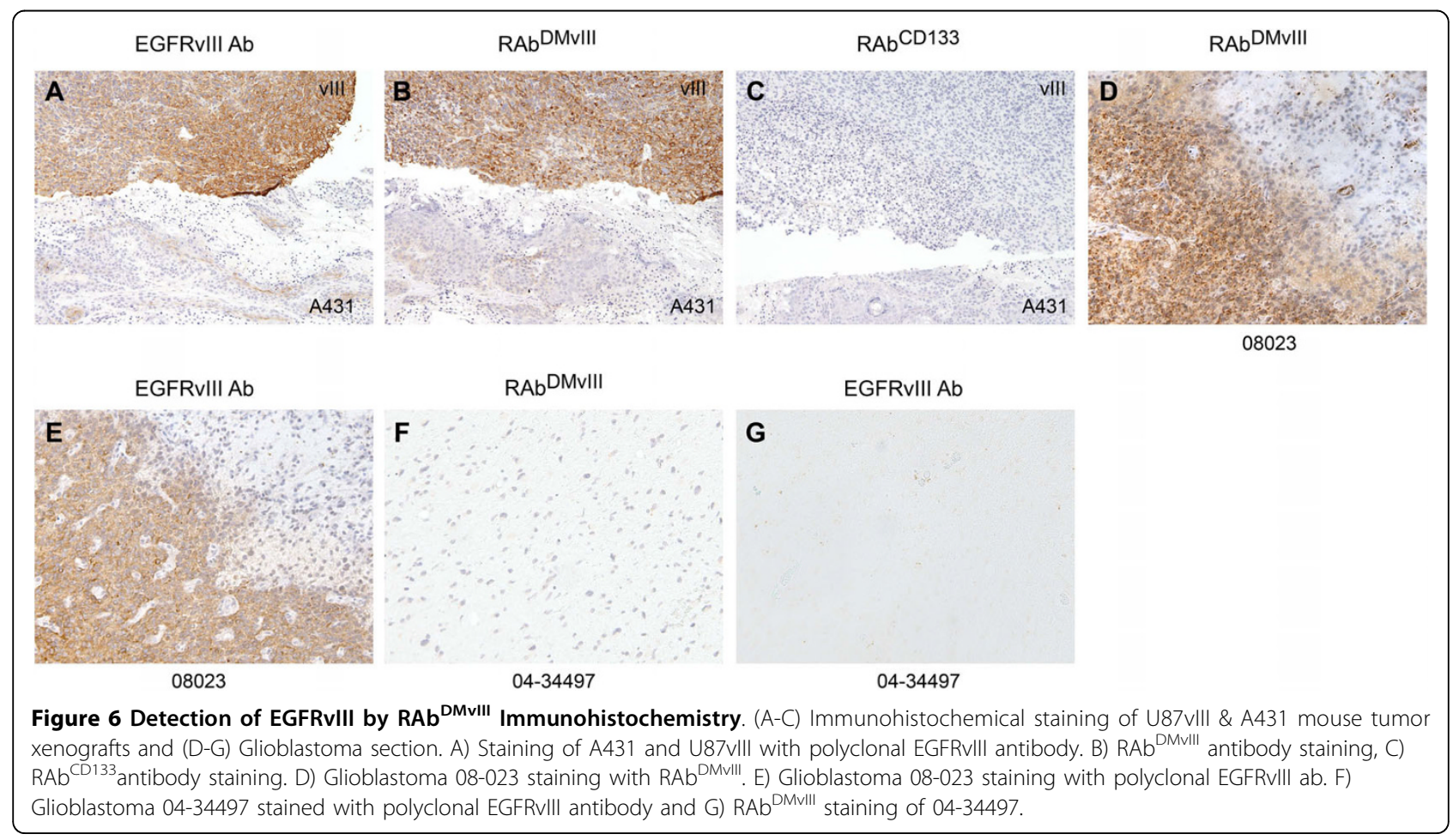



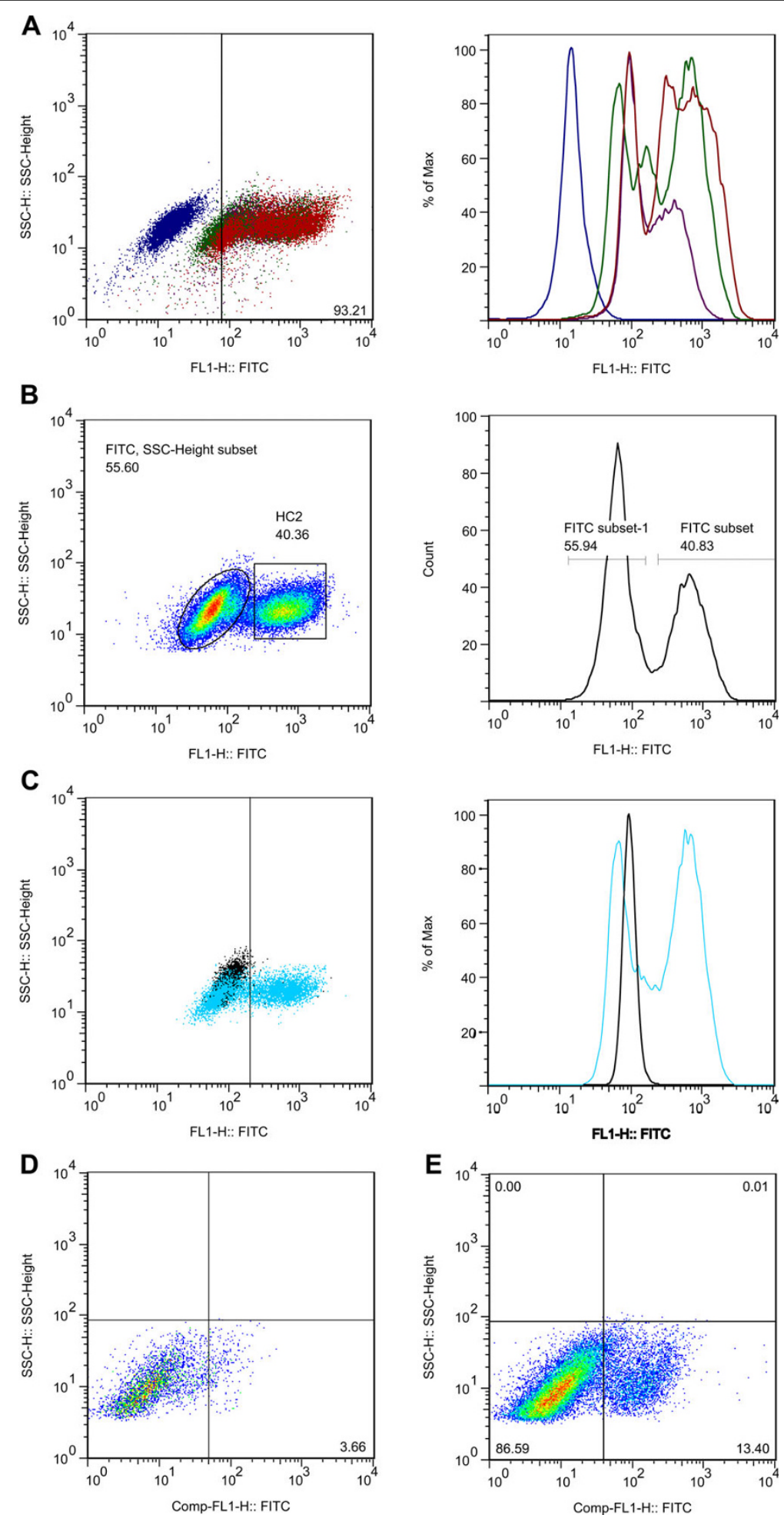

Figure 7 Specificity of RAb ${ }^{\text {DMvll1 } 1}$ by Flow cytometry. Flow cytometric analysis of surface expressed EGFRvIll. A) $1 \times 10^{6}$ cells HC2 cells were stained with increasing concentration of RAb ${ }^{\text {DMvlll: }} 0.1 \mu \mathrm{g}$ (purple), $1 \mu \mathrm{g}$ (red) and $2 \mu \mathrm{g}$ (green). The dot blot (left panel) and histogram in blue represents human-IgG1 isotype control. B) NIH3T3 and HC2 cells were mixed in a 1:1 ratio prior to staining with RAb ${ }^{\text {DMvlll }}$ revealing distinct identification of an EGFRvIll cell population. C) Overlay of flow cytometric plots of A431 (black) cells and HC2 cells (blue) stained with RAb ${ }^{\text {DMvlll }}$ showing clear selectivity for EGFRvIll expression over EGFR expression. D) Freshly dissociated human GBM tumor stained with RAb ${ }^{\text {DMvlll }}$ shows the presence of surface EGFRvIll on 13\% of cells (right panel). The dot blot (left panel) represents human-lgG1 isotype control. 
EGFRvIII antibody for scientific or clinical use. Furthermore, there is no EGFRvIII antibody clinically proven to be used on patients because of cross reactions and other high risk allergic reactions due to murine Fc portion of the monoclonal antibodies. RAb ${ }^{\mathrm{DMvIII}}$ has shown high specificity towards EGFRvIII and thus holds great potential to be further investigated for therapeutic purposes.

\section{Methods}

\section{Cell Culture}

U87-MG, HEK293, A431, and HC2 cell lines were obtained from the American Type Culture Collection (ATCC). U87-MGvIII, a human glioma cell line stably transfected with EGFRvIII, was generously donated by Dr Donald O'Rourke. Cell lines were grown in Dulbecco's modified Eagle's medium (DMEM) (glucose at 4.5 $\mathrm{g} / \mathrm{L})$ supplemented with either $10 \%$ fetal bovine serum or calf serum as per cell line requirement, 100 units $/ \mathrm{ml}$ penicillin, $100 \mu \mathrm{g} / \mathrm{ml}$ streptomycin, and $100 \mu \mathrm{g} / \mathrm{ml} \mathrm{kana}-$ mycin sulfate. The U87-MGvIII cell lines were maintained in Geneticin (G418) selection at $500 \mu \mathrm{g} / \mathrm{mL}$.

\section{Tumor Sections for Immunohistochemistry}

NOD-SCID mice were injected subcutaneously with either $1 \times 10^{6}$ U87-MGvIII or A431 cells in the right hind flank of athymic mice. After fourteen days, the mice were sacrificed and the flank tumors were dissected out and fixed in 10\% formalin. Four micron tissue sections of both A431 and U87-MGvIII tumors were cut and mounted on the same slide. Cut and mounted primary human glioblastoma tumor sections were obtained from Stanford University brain bank under IRB approved protocols.

\section{Plasmid Construction and Cloning}

The pBudCE4:Her2/neu:CD16 bispecific minibody was a kind gift from Dr. Louis Weiner [44]. This construct has an IgG1 CH3 constant domain linked to one single chain variable fragment $(\mathrm{scFv})$ against Her2/neu and one $\mathrm{scFv}$ against CD16 in a di-body format on the pBudCE4 vector backbone. The Her2/neu and CD16 variable fragments were replaced with MR1-1 [21] as described below. MR11 is a scFv against EGFRvIII selected from a phage display library which was derived from MR1 (scFv), an antibody Fv fragment that recognizes an epitope within the EGFRvIII-specific sequence. The MR1-1 scFv was artificially synthesized based on sequence available from Genbank (accession no. U76382).

The plasmid construct pBudCE4:Her2/neu: CD16 was digested with Not I and Bgl II to remove the Her2/neu scFv. The artificially synthesized MR1-1 was amplified using primers AAGGAAAAAAGCGGCCGCACCAT GGAGACAGACACACTCCTGCTATGGGTACTGCT GCTCTGGGTTCCA
GGTTCCACTGGTGGTGACGACTACAAGGACGACGATGACAAGCAGGTGAAACTGCAGCAGTCT (scFvEGFRvIII-Not1-ATG/Igk (F)) and GGAAGATCTACCGCCACTGCCACCTCCGCCTGAACCGCCTCCACCACTCGAGCCACCTTTGATTTCCAGCTTGG TGC (scFvEGFRvIII-Linker/BglII(R)) and ligated into the $\mathrm{scFv} \mathrm{Her} 2 /$ neu position. The resulting recombinant antibody was then digested with Sfil and Xba1 to remove the scFv for CD16. Primers ACATTGGTGCCGAAACCTATTCACTGCTTACTCGCGGCCCAGCC GGCCCAGGTGAAACTGCAGCAGTCT (scFvLEEKSfil(F)) and GCTCTAGAAC CGCCACTGCCACCTCC GCCTGAACCGCCTCCACCACTCGAGCCACCTTTGATTTCCAGCTTGGTGC (scFvLEEK-XbI/linker(R)) were used to amplify the second EGFRvIII scFv and ligated into the $\mathrm{scFv}$ CD16 position. The plasmid pBudCE4(scfvEGFRvIII) has the $\mathrm{CH} 3$ gene with "knobsinto-holes" configuration [45]. Additionally the V5 epitope and His6 tag sequences are cloned at the 3'-end of one anti-EGFRvIII binding arm, whereas the MYC epitope and His6 tag sequences were cloned at the 3 '-end of another anti-EGFRvIII binding arm (Figure 1). A construct with two scFvs against CD133 was created in a similar fashion as a control.

\section{Site Directed Mutagenesis}

Site directed mutagenesis was used to change tyrosine H59 of the CDRH2 domain and tyrosine H105 of the CDRH3 domain to phenylalanine for both the anti EGFRvIII scFv sequence inserts (200519-5, Stratagene). Primer CTATTCTCCTTACTCTTTTGCTATGGACTACTGGG (F) and primer CCCAGTAGTCCATAGCAAAAGAGTAAGGAGAATAG (R) were used for the $\mathrm{H} 105$ mutation while primer ACTGGCGGTTATAATACCTTCTATTCAGACAATGTAAAG (F) and primer CTTTACATTGTCTGAATAGAAGGTATTATAACC GCCAGT (R) were used for the H59 mutation. The resulting mutated vector is called pBudCE4(DMscfvEGFRvIII) and the antibody produced by this construct is called $\mathrm{RAb}^{\mathrm{DMvIII}}$ whereas the antibody produced by pBudCE4(scfvEGFRvIII) and pBudCE4(scfvCD133) are called RAb ${ }^{\mathrm{vIII}}$ and $\mathrm{RAb}^{\mathrm{CD} 133}$ respectively.

\section{Transfection, Collection and Purification of Antibody}

The pBudCE4scfvEGFRvIII, pBudCE4scfvCD133 and pBudCE4DMscfvEGFRvIII plasmids were stably transfected into HEK293 cells using calcium phosphate, and the positive clones were selected using zeocin at $400 \mu \mathrm{g} /$ $\mathrm{ml}$. Media was collected from the stably transfected cells and the His-tagged antibodies were isolated and purified using Ni-NTA agarose (R901-15, Invitrogen) according to the manufacturer's recommended protocol. The antibodies were eluted using $500 \mathrm{mM}$ imidazole. The 
fractions containing the antibodies were identified through Coomassie staining of SDS PAGE. The fractions containing the antibody protein were combined and dialyzed against phosphate buffer solution (PBS). The protein concentration was determined by a Bio-Rad Dc protein assay.

\section{Western Blot Analysis}

Confluent $\mathrm{HC} 2$ and A431 cells were washed with icecold PBS and lysed using a buffer containing $10 \mathrm{mM}$ $\mathrm{Na}_{2} \mathrm{HPO}_{4}, 150 \mathrm{mM} \mathrm{NaCl}, 1 \%$ Triton X-100, $0.5 \%$ sodium deoxycholate, $0.1 \%$ sodium dodecyl sulfate, $0.2 \%$ sodium azide, $0.004 \%$ sodium fluoride, $1 \mathrm{mM} \mathrm{NaVO}_{4}$, $25 \mathrm{mM} \beta$-glycerophosphoric acid, $100 \mu \mathrm{g}$ of phenylmethanesulfonyl fluoride/ml, $10 \mu \mathrm{g}$ of aprotinin $/ \mathrm{ml}$, and $10 \mu \mathrm{g}$ of leupeptin/ml ( $\mathrm{pH} 7.35$ ). Cell lysates were centrifuged at $12,000 \times g$ for $10 \mathrm{~min}$ at $4^{\circ} \mathrm{C}$ to clear out cell debris, and protein concentration was determined by Bio-Rad DC protein assay. For gel electrophoresis under non-reducing conditions, forty micrograms of cell lysate was prepared in 6x Laemmli Sample Buffer lacking $\beta$ mercaptoethanol and the samples were not boiled. The proteins were resolved on 4-20\% Tris-glycine SDSPAGE gels (Invitrogen) and transferred to nitrocellulose membrane for immunoblot analysis. The membranes were blocked with blocking buffer 5\% Blotto $(100 \mathrm{mM}$ Tris [pH 7.5], $0.9 \% \mathrm{NaCl}, 0.1 \%$ Tween 20 with $5 \%$ nonfat dry milk) and incubated with the following antibodies: $\mathrm{RAb}^{\mathrm{vIII}}, \mathrm{RAb}^{\mathrm{DMvIII}}$, mouse anti-actin (MAB1501R, Chemicon), and mouse anti-EGFR (E3138, Sigma Aldrich). Horse radish peroxidase (HRP) affinity pure Donkey anti-Human IgG (709-035-149, Jackson Immunoresearch) was used as the secondary for the recombinant antibodies. Proteins were detected with ECL reagents (\#RPN2106V1 and \#RPN2106V2, GE Health care).

\section{Immunoprecipitation}

HC2 (EGFRvIII transfected) and A431 (EGFR wt transfected) cell lysates were isolated as described in the western blot section and $300 \mu \mathrm{l}$ of lysate was incubated with $12 \mu \mathrm{g}$ of G100 antibody (formerly commercially available from Zymed lab, now discontinued), RAb ${ }^{\mathrm{CD} 133}$ and $\mathrm{RAb}^{\mathrm{DMvIII}}$ for $1 \mathrm{hr}$ at $4^{\circ} \mathrm{C}$. Forty $\mu \mathrm{ls}$ of washed $50 \%$ slurry of protein Gammabind G Sepharose (17-0885-01, GE Healthcare) was added to each lysate/antibody mix and incubated overnight at $4 \mathrm{C}$. Immunoprecipitates were washed three times with the same lysis buffer and resuspended in sample buffer containing $\beta$-mercaptoethanol. Immunocomplexes were resolved on 4-20\% Tris-glycine SDS-PAGE gels under normal reducing conditions and transferred to nitrocellulose membranes for immunoblot analysis by mouse anti-EGFR antibody (E3138, Sigma Aldrich).

\section{Immunofluorescence}

HC2 and A431 cells were fixed in 4\% paraformaldehyde, permeabilized with $0.5 \%$ Triton $\mathrm{X}$, and blocked with $5 \%$ goat serum (0060-01, Southern Biotech). The following antibodies were used for IF: RAb ${ }^{\text {DMvIII }}$, mouse antiEGFR (EGFR (528): sc-120, Santa Cruz Biotechnology). FITC goat anti-human (A11013, Jackson Immunoresearch) and FITC goat anti-mouse (A11029, Jackson Immunoresearch) were used as secondary antibodies. Images were obtained using a Leica SP2 AOBS Confocal Laser Scanning Microscope. For peptide competition, $\sim 20$ times higher molar concentration of EGFRvIII peptide (LEEKKGNYVVTDH-C, Genscript) and scrambled peptide (WELKVNGTKDEYH-C, Genscript) was incubated with the primary antibody at $37^{\circ} \mathrm{C}$ for 1 hour and the mixture was centrifuged at $14000 \times \mathrm{g}$ for $5 \mathrm{~min}$. The supernatant was used at the primary antibody incubation step of immunofluorescence protocol.

\section{Immunohistochemistry}

Slides were deparaffinized in xylene, and rehydrated in decreasing percentages of ethanol. 3\% hydrogen peroxide was used to block endogenous peroxidase and the slides were placed in Diva Decloaker (BioCare Medical) and microwaved for 13 minutes 10 seconds for antigen retrieval. After a cooling down period, the slides were treated with Sniper Universal serum (BioCare Medical) and then incubated with the following antibodies at 0.5 $\mu \mathrm{g} / \mathrm{ml}$ overnight at $4^{\circ} \mathrm{C}$ : Rabbit anti-EGFR antibody, $\mathrm{RAb}^{\mathrm{CD} 133}$ (recombinant negative control) and RAb ${ }^{\mathrm{DMvIII}}$. Each slide was then incubated with the appropriate secondary and/or tertiary antibody. The secondary antibodies used were: HRP-Anti Rabbit (BioCare Medical), anti-Human IgG rabbit (I9135, Sigma), HRP anti-rabbit antibody (BioCare Medical). Protein expression was detected by betazoid DAB (BioCare Medical). The slides were also counterstained with hematoxylin. Glioblastoma slides were analyzed in a similar fashion to the A431 and U87-MGvIII slides except that the slides for $\mathrm{RAb}^{\mathrm{DMvIII}}$ were blocked with equal volume of background sniper (BioCare Medical), 5\% Blotto and normal human serum (31876, Fisher) and the secondary antibody for RAb ${ }^{\text {DMvIII }}$ was rabbit anti-V5 (A00623, Genscript) followed by the tertiary antibody, which was HRP-anti-rabbit (BioCare medical).

\section{Enzyme-Linked Immunosorbent Assay (ELISA)}

To determine the affinity constant of the RAb ${ }^{\text {DMvIII }}$ a preliminary ELISA was performed to find the concentration of the antibody. This preliminary ELISA was performed with both RAb $^{\text {DMvIII }}$ and RAb ${ }^{\text {vIII }}$ antibodies to compare the dissociation constant of both the antibodies. A dilution series of antibodies $\mathrm{RAb}^{\mathrm{DMvIII}}$ and RAb ${ }^{\mathrm{vIII}}$ $(20 \mu \mathrm{g} / \mathrm{ml}-0.01952 \mu \mathrm{g} / \mathrm{ml})$ in $5 \%$ blotto was used. ELISA 
plates were first coated with $10 \mu \mathrm{g} / \mathrm{ml}$ of EGFRvIII peptide in coating solution in duplicate for each antibody overnight at $4 \mathrm{C}$. The next day the plates were washed with $1 \times$ wash buffer (50-63-00, KpL) and 5\% blotto was added for $1 \mathrm{hr}$ at RT. Thereafter the respective plates were incubated with different dilutions of RAb ${ }^{\text {DMvIII }}$ and $\mathrm{RAb}^{\mathrm{vIII}}$ ranging from $20 \mu \mathrm{g} / \mathrm{ml}$ to $0.02 \mu \mathrm{g} / \mathrm{ml}$ in $5 \%$ blotto for $1 \mathrm{hr}$ at RT. The plates were washed $3 \times 10 \mathrm{~min}$ each with $1 \times$ wash buffer, and then affinity pure Donkey antiHuman IgG (709-035-149, Jackson Immunoresearch) was applied at a 1: 5000 dilution in 5\% Blotto for $1 \mathrm{hr}$ at $\mathrm{RT}$, and then the plates were washed $3 \times 10 \mathrm{~min}$ each. $100 \mu \mathrm{l}$ of $1 \times$ developing reagent was added to each reaction well, and after $10 \mathrm{~min}$., $100 \mu \mathrm{l}$ of stop solution $1 \mathrm{~N}$ $\mathrm{HCl}$ was added and the absorbance was read at $450 \mathrm{~nm}$. All curves reached a maximum value, which indicated that the reactions proceeded until saturation. The data was plotted as the absorbance at $450 \mathrm{~nm}$ versus different antibody concentrations. This gave an equilibrium dissociation constant, $K_{d}$, for RAb ${ }^{\text {DMvIII }}$ of $886 \mathrm{nM}$ and for $\mathrm{RAb}^{\mathrm{vIII}}$ of $1.7 \mu \mathrm{M}$.

\section{Determination of Affinity Constant}

Indirect ELISA was performed to determine the affinity constant of the recombinant antibody. This method developed by Friguet et al [33] uses a solid-phase assay for measuring the amount of free antibody present at equilibrium in an antigen-antibody reaction mixture. Since the $\mathrm{RAb}^{\mathrm{DMvIII}}$ has a lower dissociation constant than $\mathrm{RAb}^{\mathrm{vIII}}$ as shown by preliminary ELISA we decided to perform indirect ELISA with RAb ${ }^{\text {DMvIII }}$ only.

Two ninety-six well ELISA plates (353279, BD Falcon) were coated overnight at $4^{\circ} \mathrm{C}$ with EGFRvIII peptide LEEKKGNYVVTDH-C at a decreasing concentration from $40 \mathrm{ug} / \mathrm{ml}$ to $2.5 \mu \mathrm{g} / \mathrm{ml}$ in coating solution (50-84$00, \mathrm{KpL})$. Wells were then blocked with $5 \%$ nonfat dry milk for $1 \mathrm{hr}$ at room temperature. In parallel tubes, antibody at $234 \mathrm{nM}$ is incubated with double the concentration of antigen used in the plates that is $(80 \mu \mathrm{g} /$ $\mathrm{ml}-5 \mu \mathrm{g} / \mathrm{ml}$ ) in equal volume for final concentration of antibody to be $117 \mathrm{nM}$ (less than the dissociation constant of $\mathrm{RAb}^{\mathrm{DMvIII}}$ ) and final antigen concentration of $(40 \mu \mathrm{g} / \mathrm{ml}-2.5 \mu \mathrm{g} / \mathrm{ml})$ for $30 \mathrm{~min}$ at $\mathrm{RT}$, and then the antibody-antigen mixture is transferred to the wells of the first antigen coated microtiter plate and incubated for $15 \mathrm{~min}$. After this incubation, the contents are then transferred to the second antigen coated plate and incubated for another $15 \mathrm{~min}$. The plates were washed with wash buffer (50-63-00, KpL) and secondary donkey antiHuman antibody from Jackson ImmunoResearch was added for $1 \mathrm{hr}$ incubation at RT. After further washes of $3 \times 10 \mathrm{~min}$ each, $100 \mu \mathrm{l}$ of substrate $(53-00-02, \mathrm{KpL})$ is applied and $100 \mu \mathrm{l}$ of stop solution $(1 \mathrm{~N} \mathrm{HCl})$ is added after $10 \mathrm{~min}$. The absorbance was read at $450 \mathrm{~nm}$ in an
ELISA plate reader. The data is plotted as the fraction of bound antibody sites versus the ratio of (fraction of bound antibody/concentration of free antigen). The slope gives the value of $\mathrm{K}$, which is the affinity constant.

\section{Flowcytometry}

Flowcytometric analysis was performed using $\mathrm{RAb}^{\mathrm{DMvIII}}$ for native cell surface expressed EGFRvIII. U87-MGwt, U87-MGvIII, A431, and HC2 cell lines were dissociated using TryplE ${ }^{\circ}$ (Invitrogen, Carlsbad, CA). Cells were resuspended in flow cytometry buffer, consisting of $1 \times$ HBSS, pH 7.2, containing $1.55 \mathrm{~g} / \mathrm{l}$ glucose and $0.1 \%$ fraction V of bovine serum albumin (BSA; Sigma-Aldrich, St. Louis,). Cells were counted and diluted to a density of $10^{6}$ cells per milliliter of buffer. $1 \mu \mathrm{g}$ of $\mathrm{RAb}^{\mathrm{DMvIII}}$ was used per $10^{6}$ cells unless otherwise specified. Cells were analyzed on a BD LSR-I flowcytometer (BD Biosciences). Unlabeled cells and cells labeled with isotype control (human IgG1) were used to set gating parameters between positive and negative cell populations. Cell aggregates and small debris were excluded from analysis or isolation on the basis of side scatter (measuring cell granularity) and forward scatter (measuring cell size); dead cells were excluded from analysis on the basis of viability dye fluorescence (propidium Iodide). Fluorescent intensities for cells in the population were point-plotted on two-axis graphs or histogram using FlowJo software (Tree Star Inc.).

\section{Acknowledgements}

We would like to thank C.D. Vecchio, S. Badal, T. Williams, and T. Lieu at Stanford University for their critical reviews of the manuscript. We would also like to thank B. Hoyte for formatting the figures. R.T. Nitta is supported by the Mark Linder/American Brain Tumor Association Fellowship. A.J. Wong is supported by National Institutes of Health grants CA69495, CA124832, CA148491 research grants from the National Brain Tumor Foundation, and the California Breast Cancer Research Program.

\section{Author details}

${ }^{1}$ Brain Tumor Research Laboratories, Department of Neurosurgery, and Program in Cancer Biology, Stanford University Medical Center, Stanford, CA94305, USA. 'Department of Gastroenterology, Henan Provincial People's Hospital, Zhenghou, Henen 450003, P.R. China.

\section{Authors' contributions}

PG performed the majority of the experiments, analyzed the data and wrote the manuscript, SYH constructed the primers for scFv EGFRvIll amplification, MHM designed the conditions to perform PCR for sCFv EGFRvIII amplification, SSM performed and analyzed FACS, GL \& RTN have been involved in the editing, revising, and formatting of the manuscript. AJW initiated the study, analyzed the data, supervised the overall project and wrote the manuscript. All authors read and approved the final manuscript.

Received: 9 June 2010 Accepted: 7 October 2010

Published: 7 October 2010

\section{References}

1. Garcia de Palazzo IE, Adams GP, Sundareshan P, Wong AJ, Testa JR, Bigner DD, Weiner LM: Expression of mutated epidermal growth factor receptor by non-small cell lung carcinomas. Cancer Res 1993, 53(14):3217-3220. 
2. Olapade-Olaopa EO, Moscatello DK, MacKay EH, Ogunbiyi JO, Shittu OB, Terry TR, Okeke LI, Wong AJ, Habib FK: A variant epidermal growth factor receptor protein is similarly expressed in benign hyperplastic and carcinomatous prostatic tissues in black and white men. West Afr J Med 2007, 26(1):42-47.

3. Wong AJ, Bigner SH, Bigner DD, Kinzler KW, Hamilton SR, Vogelstein B: Increased expression of the epidermal growth factor receptor gene in malignant gliomas is invariably associated with gene amplification. Proc Natl Acad Sci USA 1987, 84(19):6899-6903.

4. Libermann TA, Nusbaum HR, Razon N, Kris R, Lax I, Soreq H, Whittle N, Waterfield MD, Ullrich A, Schlessinger J: Amplification, enhanced expression and possible rearrangement of EGF receptor gene in primary human brain tumours of glial origin. Nature 1985, 313(5998):144-147.

5. Ekstrand AJ, Sugawa N, James CD, Collins VP: Amplified and rearranged epidermal growth factor receptor genes in human glioblastomas reveal deletions of sequences encoding portions of the $\mathrm{N}$ - and/or C-terminal tails. Proc Natl Acad Sci USA 1992, 89(10):4309-4313.

6. Wikstrand CJ, Hale LP, Batra SK, Hill ML, Humphrey PA, Kurpad SN, McLendon RE, Moscatello D, Pegram CN, Reist CJ, et al: Monoclonal antibodies against EGFRvIll are tumor specific and react with breast and lung carcinomas and malignant gliomas. Cancer Res 1995, 55(14):3140-3148.

7. Ge H, Gong X, Tang CK: Evidence of high incidence of EGFRvIll expression and coexpression with EGFR in human invasive breast cancer by laser capture microdissection and immunohistochemical analysis. Int $J$ Cancer 2002, 98(3):357-361.

8. Luo X, Gong X, Tang CK: Suppression of EGFRvlll-mediated proliferation and tumorigenesis of breast cancer cells by ribozyme. Int J Cancer 2003, 104(6):716-721.

9. Okamoto I, Kenyon LC, Emlet DR, Mori T, Sasaki J, Hirosako S, Ichikawa Y, Kishi H, Godwin AK, Yoshioka M, et al: Expression of constitutively activated EGFRvIll in non-small cell lung cancer. Cancer Sci 2003, 94(1):50-56

10. Aldape KD, Ballman K, Furth A, Buckner JC, Giannini C, Burger PC Scheithauer BW, Jenkins RB, James CD: Immunohistochemical detection of EGFRvIll in high malignancy grade astrocytomas and evaluation of prognostic significance. J Neuropathol Exp Neurol 2004, 63(7):700-707.

11. Cunningham MP, Essapen S, Thomas H, Green M, Lovell DP, Topham C, Marks C, Modjtahedi $\mathrm{H}$ : Coexpression, prognostic significance and predictive value of EGFR, EGFRvIII and phosphorylated EGFR in colorectal cancer. Int J Oncol 2005, 27(2):317-325.

12. Heimberger $A B$, Crotty LE, Archer GE, Hess KR, Wikstrand CJ, Friedman AH, Friedman HS, Bigner DD, Sampson JH: Epidermal growth factor receptor VIII peptide vaccination is efficacious against established intracerebral tumors. Clin Cancer Res 2003, 9(11):4247-4254.

13. Moscatello DK, Holgado-Madruga M, Godwin AK, Ramirez G, Gunn G, Zoltick PW, Biegel JA, Hayes RL, Wong AJ: Frequent expression of a mutant epidermal growth factor receptor in multiple human tumors. Cancer Res 1995, 55(23):5536-5539.

14. Sampson JH, Crotty LE, Lee S, Archer GE, Ashley DM, Wikstrand CJ, Hale LP, Small C, Dranoff G, Friedman AH, et al: Unarmed, tumor-specific monoclonal antibody effectively treats brain tumors. Proc Natl Acad Sci USA 2000, 97(13):7503-7508.

15. Heimberger $A B$, Hlatky $R$, Suki D, Yang D, Weinberg J, Gilbert M, Sawaya $R$ Aldape K: Prognostic effect of epidermal growth factor receptor and EGFRvIll in glioblastoma multiforme patients. Clin Cancer Res 2005 11(4):1462-1466.

16. Sugawa N, Ekstrand AJ, James CD, Collins VP: Identical splicing of aberrant epidermal growth factor receptor transcripts from amplified rearranged genes in human glioblastomas. Proc Natl Acad Sci USA 1990, 87(21):8602-8606.

17. Humphrey PA, Gangarosa LM, Wong AJ, Archer GE, Lund-Johansen M, Bjerkvig R, Laerum OD, Friedman HS, Bigner DD: Deletion-mutant epidermal growth factor receptor in human gliomas: effects of type II mutation on receptor function. Biochem Biophys Res Commun 1991, 178(3):1413-1420.

18. Wong AJ, Ruppert JM, Bigner SH, Grzeschik CH, Humphrey PA, Bigner DS, Vogelstein B: Structural alterations of the epidermal growth factor receptor gene in human gliomas. Proc Natl Acad Sci USA 1992, 89(7):2965-2969.
19. Grandis JR, Sok JC: Signaling through the epidermal growth factor receptor during the development of malignancy. Pharmacol Ther 2004, 102(1):37-46.

20. Moscatello DK, Ramirez G, Wong AJ: A naturally occurring mutant human epidermal growth factor receptor as a target for peptide vaccine immunotherapy of tumors. Cancer Res 1997, 57(8):1419-1424.

21. Kuan CT, Srivastava N, McLendon RE, Marasco WA, Zalutsky MR, Bigner DD: Recombinant single-chain variable fragment antibodies against extracellular epitopes of human multidrug resistance protein MRP3 for targeting malignant gliomas. Int J Cancer 2009.

22. Wikstrand CJ, Cokgor I, Sampson JH, Bigner DD: Monoclonal antibody therapy of human gliomas: current status and future approaches. Cancer Metastasis Rev 1999, 18(4):451-464.

23. Sampson JH, Archer GE, Mitchell DA, Heimberger AB, Bigner DD: Tumorspecific immunotherapy targeting the EGFRvIll mutation in patients with malignant glioma. Semin Immunol 2008, 20(5):267-275.

24. Schmittling RJ, Archer GE, Mitchell DA, Heimberger A, Pegram C, Herndon JE, Friedman HS, Bigner DD, Sampson JH: Detection of humoral response in patients with glioblastoma receiving EGFRvIll-KLH vaccines. J Immunol Methods 2008, 339(1):74-81.

25. Adams GP, Schier R, McCall AM, Simmons HH, Horak EM, Alpaugh RK, Marks JD, Weiner LM: High affinity restricts the localization and tumor penetration of single-chain fv antibody molecules. Cancer Res 2001, 61(12):4750-4755.

26. Langmuir VK, Mendonca HL, Woo DV: Comparisons between two monoclonal antibodies that bind to the same antigen but have differing affinities: uptake kinetics and 125l-antibody therapy efficacy in multicell spheroids. Cancer Res 1992, 52(17):4728-4734.

27. Jungbluth AA, Stockert E, Huang HJ, Collins VP, Coplan K, Iversen K, Kolb D, Johns TJ, Scott AM, Gullick WJ, et al: A monoclonal antibody recognizing human cancers with amplification/overexpression of the human epidermal growth factor receptor. Proc Natl Acad Sci USA 2003, 100(2):639-644.

28. Bird RE, Hardman KD, Jacobson JW, Johnson S, Kaufman BM, Lee SM, Lee T, Pope SH, Riordan GS, Whitlow M: Single-chain antigen-binding proteins. Science 1988, 242(4877):423-426.

29. Beers R, Chowdhury P, Bigner D, Pastan I: Immunotoxins with increased activity against epidermal growth factor receptor vlll-expressing cells produced by antibody phage display. Clin Cancer Res 2000, 6(7):2835-2843.

30. Patel D, Lahiji A, Patel S, Franklin M, Jimenez X, Hicklin DJ, Kang X: Monoclonal antibody cetuximab binds to and down-regulates constitutively activated epidermal growth factor receptor vill on the cell surface. Anticancer Res 2007, 27(5A):3355-3366.

31. Landry RC, Klimowicz AC, Lavictoire SJ, Borisova S, Kottachchi DT, Lorimer IA, Evans SV: Antibody recognition of a conformational epitope in a peptide antigen: Fv-peptide complex of an antibody fragment specific for the mutant EGF receptor, EGFRvill. J Mol Biol 2001, 308(5):883-893.

32. Johns TG, Adams TE, Cochran JR, Hall NE, Hoyne PA, Olsen MJ, Kim YS, Rothacker J, Nice EC, Walker F, et al: Identification of the epitope for the epidermal growth factor receptor-specific monoclonal antibody 806 reveals that it preferentially recognizes an untethered form of the receptor. J Biol Chem 2004, 279(29):30375-30384.

33. Friguet $B$, Chaffotte AF, Djavadi-Ohaniance L, Goldberg ME: Measurements of the true affinity constant in solution of antigen-antibody complexes by enzyme-linked immunosorbent assay. J Immunol Methods 1985, 77(2):305-319.

34. Wikstrand CJ, McLendon RE, Friedman AH, Bigner DD: Cell surface localization and density of the tumor-associated variant of the epidermal growth factor receptor, EGFRvIll. Cancer Res 1997, 57(18):4130-4140.

35. Coloma MJ, Morrison SL: Design and production of novel tetravalent bispecific antibodies. Nat Biotechnol 1997, 15(2):159-163.

36. Merchant AM, Zhu Z, Yuan JQ, Goddard A, Adams CW, Presta LG, Carter P. An efficient route to human bispecific IgG. Nat Biotechnol 1998, 16(7):677-681.

37. Ridgway JB, Presta LG, Carter P: 'Knobs-into-holes' engineering of antibody $\mathrm{CH} 3$ domains for heavy chain heterodimerization. Protein Eng 1996, 9(7):617-621. 
38. Robinson MK, Weiner LM, Adams GP: Improving Monoclonal Antibodies For Cancer Therapy. Drug Development research 2004, 61:172-187.

39. Fujimori $\mathrm{K}$, Covell DG, Fletcher JE, Weinstein JN: A modeling analysis of monoclonal antibody percolation through tumors: a binding-site barrier. J Nucl Med 1990, 31(7):1191-1198.

40. Fujimori $\mathrm{K}$, Covell DG, Fletcher JE, Weinstein JN: Modeling analysis of the global and microscopic distribution of immunoglobulin $G, F\left(a b^{\prime}\right) 2$, and Fab in tumors. Cancer Res 1989, 49(20):5656-5663.

41. Van Osdol W, Fujimori K, Weinstein JN: An analysis of monoclonal antibody distribution in microscopic tumor nodules: consequences of a "binding site barrier". Cancer Res 1991, 51(18):4776-4784.

42. Robinson MK, Weiner LM, Adams GP: Improving Monoclonal Antibodies For Cancer Therapy. Drug Development research 2004, 61:172-187.

43. Mukasa A, Wykosky J, Ligon KL, Chin L, Cavenee WK, Furnari F: Mutant EGFR is required for maintainenece of glioma growth in vivo, and its ablation leads to escape from receptor dependence. Proc Natl Acad Sci USA 2010, 107(6):2616-21.

44. Weiner LM: Bispecific antibodies in cancer therapy. Cancer J 2000, 6(Suppl 3):S265-271.

45. Shahied LS, Tang Y, Alpaugh RK, Somer R, Greenspon D, Weiner LM: Bispecific minibodies targeting HER2/neu and CD16 exhibit improved tumor lysis when placed in a divalent tumor antigen binding format. J Biol Chem 2004, 279(52):53907-53914.

doi:10.1186/1472-6750-10-72

Cite this article as: Gupta et al:: Development of an EGFRvIll specific recombinant antibody. BMC Biotechnology 2010 10:72.

\section{Submit your next manuscript to BioMed Central and take full advantage of:}

- Convenient online submission

- Thorough peer review

- No space constraints or color figure charges

- Immediate publication on acceptance

- Inclusion in PubMed, CAS, Scopus and Google Scholar

- Research which is freely available for redistribution

Submit your manuscript at www.biomedcentral.com/submit 